\title{
Primitive erythropoiesis in the mammalian embryo
}

\author{
JAMES PALIS*, JEFFREY MALIK, KATHLEEN E. MCGRATH and PAUL D. KINGSLEY \\ University of Rochester Medical Center, Department of Pediatrics, \\ Center for Pediatric Biomedical Research, New York, USA
}

\begin{abstract}
Erythropoiesis in adult mammals is characterized by the progressive maturation of hematopoietic stem cells to lineage-specific progenitors, to morphologically identifiable precursors which enucleate to form mature erythrocytes. In contrast, primitive erythropoiesis is characterized by the appearance within the yolk sac of a transient, lineage-restricted progenitor population which generates a wave of erythroid precursors. These precursors undergo progressive maturation in the bloodstream, characterized by nuclear condensation and embryonic hemoglobin accumulation. This process is dependent on erythropoietin signaling through its cognate receptor, as well as the function of several erythroid-specific transcription factors, including GATA1 and EKLF. Targeted disruption of genes in the mouse that result in failure of the emergence or maturation of the primitive erythroid lineage leads to early fetal death, indicating that the primitive erythroid lineage is necessary for survival of the mammalian embryo. While it was thought for over a century that primitive erythroid cells were uniquely nucleated mammalian red cells, it is now recognized that they, like their definitive erythroid counterparts, enucleate to form reticulocytes and pyrenocytes. This surprising finding indicates that the primitive erythroid lineage is indeed mammalian, rather than non-mammalian, in character.
\end{abstract}

KEY WORDS: erythropoiesis, enucleation, yolk sac

\section{Emergence of the primitive erythroid lineage from hemangioblast precursors}

The first morphological evidence of hematopoiesis in multiple mammalian embryos, including cat, hamster, mouse, gerbil and human, is the appearance of pools of immature erythroid cells within the mesoderm layer of the yolk sac (Sorenson, 1961; Smith, 1977; Tiedemann, 1977; Haar, 1971; Takashina, 1987). These "blood islands" consist of immature primitive erythroid cells that rapidly become enveloped by endothelial cells (reviewed by Ferkowicz, 2005). The close spatial and temporal appearance of blood cells and endothelial cells in the yolk sac suggested to embryologists of the last century that these lineages arise from hemangioblast precursors (Sabin, 1920). This concept has been verified in mouse embryos where cells with hematopoietic, endothelial, and smooth muscle potential arise during gastrulation in the primitive streak (Huber, 2004; reviewed by Park, 2005). Studies of human embryonic stem cells cultured as embryoid bodies provide in vitro evidence that similar events occur in the human (Zambidis, 2005; Kennedy, 2007). Emergence of hematopoietic fates from a flk-1-positive hemangioblast involves transition through a "hemogenic" endothelial intermediate (Lancrin,
2009; Eilken, 2009). Further support of this transition comes from flow cytometric studies indicating that primitive erythroid potential emerges from endothelial marker-positive (VE-cadherin-, PECAM1-, CD34-, endoglin-, and Tie2-positive) cells (Ema, 2006). Recent lineage tracing studies also indicate that primitive and adult blood cells ultimately derive from flk-1-positive cells (Lugus, 2009). While the current data support the concept that hematopoiesis in the yolk sac arises from hemangioblast precursors, it is not clear if the endothelial and smooth muscle fates are realized in vivo (Ueno, 2006; Furuta, 2006).

\section{Specification of primitive erythropoiesis}

The yolk sac forms as a bilayered structure with mesoderm cells apposed to visceral endoderm cells (Jollie, 1990). Support for the role of visceral endoderm in mammalian blood cell formation comes from GATA-4-null embryonic stem cell-derived embryoid bodies that lack visceral endoderm and display markedly reduced blood island formation (Bielinska, 1996). Tissue recom-

Abbreviations used in this paper: EryP-CFC, primitive erythroid colony-forming cells.

*Address correspondence to: James Palis. University of Rochester Medical Center, Department of Pediatrics, Center for Pediatric Biomedical Research 601 Elmwood Ave, Rochester, New York 14642, USA. Fax +1-585-276-0232. e-mail: james_palis@urmc.rochester.edu

Final, author-corrected PDF published online: 16 July 2010.

ISSN: Online 1696-3547, Print 0214-6282

() 2010 UBC Press

Printed in Spain 
bination experiments in the mouse suggest that these endoderminducing signals act during early gastrulation, are diffusible, and appear to involve Hedgehog signaling (Belaousoff, 1999; Dyer, 2001). While the downstream targets of Hedgehog signaling have not been elucidated, bone morphogenetic protein 4 (BMP4) is one possible candidate. Mouse embryos lacking BMP4 have a paucity of yolk sac blood islands and die in early post-implantation stages because of defects in mesoderm formation (Winnier, 1995). Exogenous BMP4 mediates the development of mesoderm cells in embryonic stem cell-derived embryoid bodies grown under serum free conditions (Johansson, 1995; Pearson, 2008). It has recently been established that specification of the primitive erythroid lineage is controlled by the coordinated interaction of the Wnt pathway with inhibition of the Notch signaling pathway in hemangioblast precursors (Cheng, 2008). However, examination of Notch1-null embryos reveals normal specification of the primitive erythroid lineage (Hadland, 2004) but an apparent expansion of maturing primitive erythroid cells due to decreased apoptosis (Robert-Moreno, 2007). Taken together, these studies indicate that multiple signaling cascades coordinately regulate the spatiotemporal emergence of the primitive erythroid lineage during gastrulation in the mammalian embryo.

\section{Primitive erythroid progenitors (EryP-CFC)}

The identification of primitive erythroid progenitors (EryPCFC), capable of forming colonies of erythroid cells in vitro, constitutes the earliest evidence that mesoderm cells have committed to a hematopoietic fate in the mouse conceptus (Wong, 1986). Murine EryP-CFC form compact colonies of large primitive erythroid cells that require 4-5 days to mature in vitro (Fig. 1). Examination of carefully staged mouse embryos indicate that EryP-CFC first emerge within the developing yolk sac at the late primitive streak stage (approximately E7.25), after the onset of gastrulation but before morphological evidence of blood island formation (Palis, 1999). These primitive erythroid progenitors express low levels of CD41 on their surface (Ferkowicz, 2003). EryP-CFC expand in number for 48 hours within the developing yolk sac, but then are rapidly extinguished by E9.0 (Palis, 1999). EryP-CFC are not found in any other time or place in the murine embryo. The restricted spatial and temporal appearance of EryPCFC indicates that primitive erythropoiesis is transient in nature.

Recently, bipotential primitive erythroid/megakaryocyte progenitors have been found in the gastrulating mouse embryo (Tober, 2007). These progenitors emerge and are extinguished

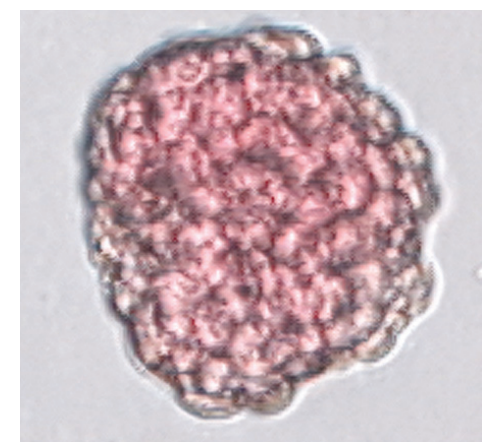

Fig. 1. Primitive erythroid precursor (EryP-CFC)-derived colony of primitive erythroid cells cultured in semi-solid medium. with the same kinetics as EryP-CFC. The emergence of the primitive erythroid and megakaryocyte lineages from a common progenitor indicates that "primitive" hematopoiesis in the yolk sac is at least bilineage in character and thus more complex than previously thought.

Erythropoietin receptor (EPO-R) transcripts are first detected in nascent yolk sac blood islands of mouse embryos beginning at $\mathrm{E} 7.5$ and increase in concentration as primitive erythroid precursors begin to mature (McGann, 1997; Lee, 2001). Decreasing numbers of EPO-R have been detected on the cell surface of terminally differentiating primitive erythroid cells in the fetal hamster (Boussios, 1989). The role of erythropoietin in the differentiation of yolk sac erythroblasts remains somewhat controversial. Initial studies indicated that the addition of exogenous erythropoietin did not increase heme synthesis when whole primitive streak to $20 \mathrm{sp}$ mouse embryos were cultured intact (Cole, 1966). However, a subsequent study from the same laboratory revealed a significant increase in heme synthesis when erythropoietin was added to cultures of disaggregated 0-12 sp embryonic cells (Bateman, 1971). These latter findings were confirmed by culture of E7.5 yolk sac explants where the addition of exogenous erythropoietin increased the number of erythroid cells and the accumulation of embryonic globin transcripts (Palis, 1995). Exogenous erythropoietin abrogates apoptosis of immature primitive erythroid cells cultured in vitro (Kimura, 2000). While high levels of erythropoietin transcripts have been found in the fetal liver as early as E10.25 (Makita, 2001), the endogenous source of erythropoietin at earlier developmental time-points remains controversial (Zimmerman, 1997; Lee, 2001).

Engagement of the homodimeric EPO-R by erythropoietin leads to autophosphorylation of the Janus kinase 2 (JAK2) and subsequent phosphorylation of several tyrosine residues of the cytoplasmic tail of EPO-R (reviewed by Richmond, 2005). The critical role of JAK2 in EPO-R signaling was established by examination of the phenotype of JAK2-null mice, which phenocopy the severe fetal anemia and in utero death of the erythropoietin-null and EPO-R-null embryos (Neubauer, 1998). Phosphorylation of tyrosine residues in the cytoplasmic region of EPO-R leads to the recruitment of multiple signaling molecules, including the signal transducer and activator of transcription 5 (STAT5). STAT5 subsequently translocates to the nucleus to regulate the transcription of the antiapoptotic gene $\mathrm{Bcl}-\mathrm{x}(\mathrm{L})$ and enhance definitive erythroid cell survival (Silva, 1999). Robust STAT5 signaling has been detected in primitive erythroid cells derived from the in vitro culture of murine embryonic stem cells (TsujiTakayama, 2005). Bcl-x(L) protects primitive erythroid cells from apoptosis (Motoyama, 1999).

The functional role of erythropoietin signaling through its cognate receptor has been demonstrated by the similar phenotype of mice with targeted disruption of erythropoietin compared to disruption of EPO-R (Wu, 1995; Lin, 1996; Kieran, 1996). The loss of either gene leads to a 5 to 20 -fold reduction in number of circulating primitive erythroblasts by E11.5 and the mutant embryos die with severe anemia by $\mathrm{E} 13.5$. These results indicate that signaling through the erythropoietin receptor is critically important for the normal maturation of primitive erythroid cells. However, unlike the complete dependence of definitive erythropoiesis on erythropoietin signaling, some EPO-R-null primitive erythroid cells do appear to complete their maturation, suggesting 

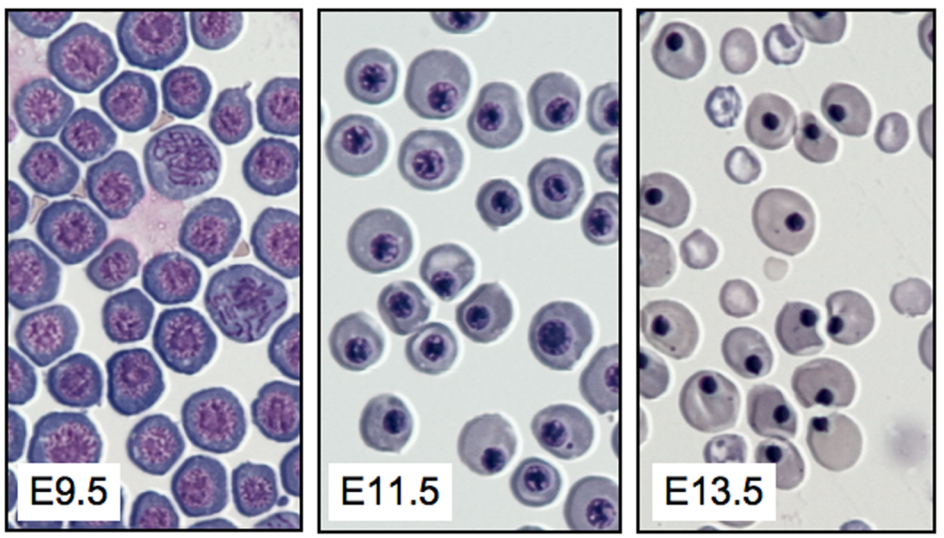

Fig. 2. Peripheral blood cells from E9.5, E11.5, E13.5 and E15.5 of mouse development. The synchronous, progressive maturation of primitive erythroid cells from immature erythroblasts to enucleated erythrocytes (arrowhead) is evident.

that other cytokine signaling cascades also function to support the maturation of primitive erythroid precursors.

\section{Maturation of primitive erythroid precursors}

The transient appearance of EryP-CFC leads to the generation of a wave of synchronously maturing erythroid precursors. Immature primitive erythroblasts begin to enter the bloodstream with the onset of cardiac contractions (McGrath, 2003; Ji, 2003). These cells are extremely large in size, attaining volumes between 400-700 femtoliters (Kingsley, 2004). Evaluation of blood smears from progressive times of hamster and of mouse embryogenesis reveals the morphological changes classically associated with definitive erythroid precursor maturation in the adult marrow, including decrease in erythroblast cell size, nuclear condensation with loss of euchromatin, and hemoglobin accumulation (Fig. 2; Sasaki, 1985; Kingsley, 2004; Fraser, 2007). The latter, in association with decreased RNA levels, results in loss of cytoplasmic basophilia observed following Wright-Giemsa staining.

Like definitive erythropoiesis, the maturation of primitive erythroid precursors is associated with several cell divisions that result in amplified numbers of erythroblasts. We have found that primitive erythroblast numbers expand 100-fold between E8.5 and E10.5 of mouse gestation. The presence of mitotic cells in the bloodstream (Bethlemfalvay, 1970), thymidine incorporation studies (de la Chapelle, 1969), and cell cycle analysis (Sangiorgi, 1990 ) indicate that circulating murine primitive erythroblasts cease dividing byE13.5. Primitive erythroblasts rapidly accumulate hemoglobin. As early as E9, they contain $22 \mathrm{pg} / \mathrm{cell}$ of hemoglobin, which is the same amount present in fully mature adult erythrocytes (Steiner, 1973). Consistent with their large size, primitive erythroblasts continue to accumulate hemoglobin, ultimately achieving steady state levels of 80-100 pg/cell (Fantoni, 1969; Steiner, 1973). It is not known when transcription ceases in maturing erythroid precursors. However, synthesis of non-heme proteins ceases by E12.5, while hemoglobin synthesis directed by stable globin transcripts continues until E14.5 (Fantoni, 1968).

\section{"Maturational" globin switching}

It was recognized several decades ago that embryonic (primi-

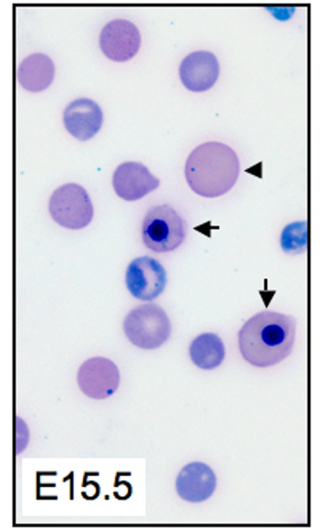

tive) erythroblasts contained different hemoglobins when compared with adult (definitive) erythrocytes (Barker, 1968). Primitive erythroid cells in the mouse express not only embryonic $(\beta \mathrm{H} 1$ and zy) globins but also low levels of adulttype ( $\beta 1$ and $\beta 2$ ) globins (Brotherton, 1979). Embryonic hemoglobins in the mouse have a high affinity for oxygen, presumably to facilitate oxygen exchange across the placenta (Wells, 1979). Initial studies suggested that the levels of $\beta \mathrm{H} 1$ - and $\varepsilon y$-globin transcripts were dynamically regulated during embryogenesis (Farace, 1984; Whitelaw, 1991). A more recent analysis of globin gene expression during the maturation of primitive erythroid precursors has confirmed and extended these findings by specifically examining primitive versus definitive erythroid cells (Kingsley, 2006). Surprisingly, $\beta \mathrm{H} 1$-globin transcripts were detected prior to $\varepsilon y$-globin transcripts as blood islands begin to form in the murine yolk sac at E7.5. By E10.5, maturing primitive erythroid cells contained approximately equal quantities of $\beta \mathrm{H} 1$ - and $\varepsilon y$-globin transcripts as well as low levels of the "adult" $\beta 1$ - and $\beta 2$-globin transcripts. By E15.5, عy-globin was the predominant $\beta$-globin transcript in primitive erythroid reticulocytes (Kingsley, 2006). Thus, there is a $\beta \mathrm{H} 1$ - to $\varepsilon y$-globin "switch" as primitive erythroid cells mature (Fig. 3 ). Switching within the $\alpha$-globin locus was also found, with a transition from $\zeta$ - plus $\alpha$-globin to entirely $\alpha$-globin transcript expression in primitive erythroid cells (Fig. 3; Kingsley, 2006). These findings indicate that the $\alpha$ - and $\beta$-globin loci are actively regulated in the primitive erythroid lineage as the cells transition from progenitors to increasingly more mature precursors.

The study of primary human primitive erythroblasts indicate that they also undergo a $\zeta$ - to $\alpha$-globin switch between 5 and 7 weeks gestation (Peschle, 1985). The culture of human embryonic stem cells leads to the generation of primitive erythroblasts, thus permitting access to cells that would otherwise be difficult or impossible to study due to ethical and practical concerns. Recent studies of embryonic stem cell-derived human primitive erythroblasts indicate that they, like their primary counterparts, undergo a "maturational" switch from hemoglobin Gower I $\left(\zeta_{2} \varepsilon_{2}\right)$ to hemoglobin Gower II $\left(\alpha_{2} \varepsilon_{2}\right)$ (Qiu, 2008).

\section{Enucleation of primitive erythroblasts}

The red cells of mammals circulate as enucleated erythrocytes. In contrast, the red cells of birds, amphibians and fish circulate as nucleated cells throughout their life span. The presence of nucleated primitive erythroid cells in mammalian embryos has raised the possibility that this lineage shares many features with their non-mammalian counterparts. However, in the early 1970's, enucleated «megalocytes» having the same size and hemoglobin content as nucleated yolk sac erythroblasts were detected at later times of mouse gestation (Fig. 2, arrowhead; Bethlemfalvay, 1970; Steiner, 1973). These cells are 3-fold larger than the fetal liver-derived «macrocytes» that enter the bloodstream beginning at E12.5 (Steiner, 1973), and were postulated 
to be primitive erythroblasts that had undergone enucleation. While nucleated yolk sac-derived erythroid cells are no longer present in the bloodstream after E16.5 (Brotherton, 1979), megalocytes were found in the bloodstream until E18.5 (Bethlemfalvay, 1970; Steiner, 1973). Primitive erythroblasts also undergo other changes during their maturation consistent with enucleation, including the loss of the intermediate filament vimentin (Sangiorgi, 1990) and the loss of histone proteins (Morioka, 1998). Furthermore, murine primitive erythroblasts examined at E12.5 contain little evidence of marginal bands (Koury, 1987), the circumferential set of microtubules found in avian and amphibian erythrocytes.

Using antibodies specific for embryonic globins to identify primitive erythroid cells, it was determined that primitive erythroblasts in the mouse fetus enucleate between E12.5-E16.5 of gestation (Kingsley, 2004). Enucleated primitive erythrocytes have been identified in the bloodstream of mice even several days after birth (Kingsley, 2004). These surprising findings have been confirmed more recently using mice containing a GFP transgene driven by the human $\varepsilon$-globin promoter to identify primitive erythroid cells (Fraser, 2007). Enucleation of erythroid cells in the marrow results in the formation of two daughter cells. The first is the anucleate reticulocyte that completes its maturation by removing internal organelles and reorganizing its cytoskeleton. The second consists of the condensed nucleus surrounded by a thin rim of cytoplasm and an intact cell membrane. This second cell, recently termed "pyrenocyte", is rapidly ingested by macrophages (McGrath, 2008; Yoshida, 2005). Primitive pyrenocytes that appear to have temporarily escaped this fate have been detected in the bloodstream of mouse embryos between E12.5-E16.5 of gestation, that is, during the time when primitive erythroid cells enucleate (McGrath, 2008). Interestingly, primitive erythroblasts are capable of physically interacting with macrophage cells in vitroand are thought to do so within the fetal liver in vivo(McGrath, 2008; Isern, 2008). These interactions are mediated in part through $\alpha 4 \beta 1$ integrins present on the surface of primitive erythroid cells and are presumed to involve VCAM1 expressed by macrophage cells in the fetal liver (McGrath, 2008; Isern, 2008). These observations, taken together, indicate that terminal differentiation of mammalian primitive erythroid cells results in erythrocytes more similar to the enucleated red cells of mammals rather than the nucleated red cells of birds, fish and amphibians.

\section{Transcriptional regulation of primitive erythropoiesis}

Lineage differentiation in the hematopoietic system and terminal maturation of erythroid cells are regulated in part by the differential expression and combinatorial action of transcription factors. Two transcription factors in particular, GATA1 and KLF1, play central roles in erythroid-specific transcription by forming complexes with multiple other proteins to upregulate the expression of erythroid-specific genes.

GATA1 is the founding member of the GATA transcription factor family of dual zinc finger proteins that bind a WGATAR consensus motif present in essentially all erythroid-specific genes. GATA1 is expressed in nascent blood islands of the yolk sac (Fig. 4; Silver, 1997). Targeted disruption of GATA1 in the mouse leads to a block of primitive erythroid cell maturation at the proerythroblast stage of maturation. This block of primitive erythropoiesis results in embryonic death between E9.5-10.5, prior to the shift of hematopoiesis from the yolk sac to the fetal liver (Fujiwara, 1996). Different functional domains of GATA1 are required for activation of target genes in primitive versus definitive erythroid cells suggesting that different transcriptional complexes may form in these lineages (Shimizu, 2001). A screen of proteins that bind to GATA1 led to the identification of Friend of GATA (FOG1), a zinc finger protein that binds the amino zinc finger of GATA1 (Tsang, 1997). Like mice lacking GATA1, FOG1-null primitive erythroid cells also arrest at the proerythroblast stage of maturation and the embryos die of severe anemia at E10.5-E11 (Tsang, 1998).

Studies of definitive erythroid cells lacking GATA1 indicate that GATA2, which is present on GATA-binding sites, is displaced by GATA1 as erythroid lineage differentiation proceeds (Grass, 2003; Grass, 2006). Interestingly, between E7.5 and E8.5 a reciprocal downregulation of GATA2 and upregulation of GATA1 has been detected in yolk sac blood islands (Silver, 1997), suggesting that a GATA switch may occur as primitive erythroid cells transition from progenitors to precursors in vivo. Recent genome-wide approaches are defining the genes potentially upand down-regulated by GATA1 in definitive erythroid cells (Yu, 2009; Chang, 2009; Fujiwara, 2009). Similar studies in primitive erythroid cells have not yet been reported.

The helix-loop-helix stem cell leukemia gene (Scl, Tal1) and the Lim domain-containing transcription factor Lmo2 are also found in a multiprotein complex with GATA1 in adult erythroid
Fig. 3. Primitive erythroid cells undergo "maturational" switches of their $\beta$ - and $\alpha$-globin genes as they mature in vivo. Relative levels of the various globin transcripts in primitive erythroid cells at various developmental times are shown. Schematic diagrams of the $\beta$-and $\alpha$-globin loci are also shown.
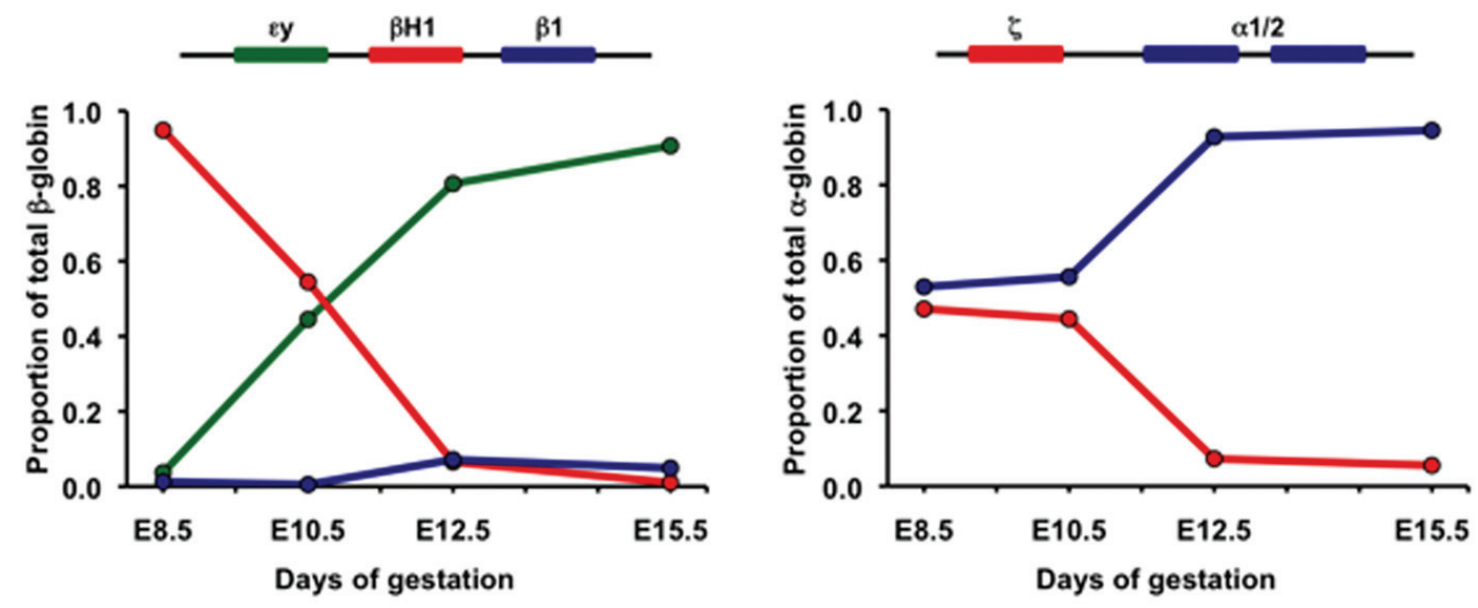


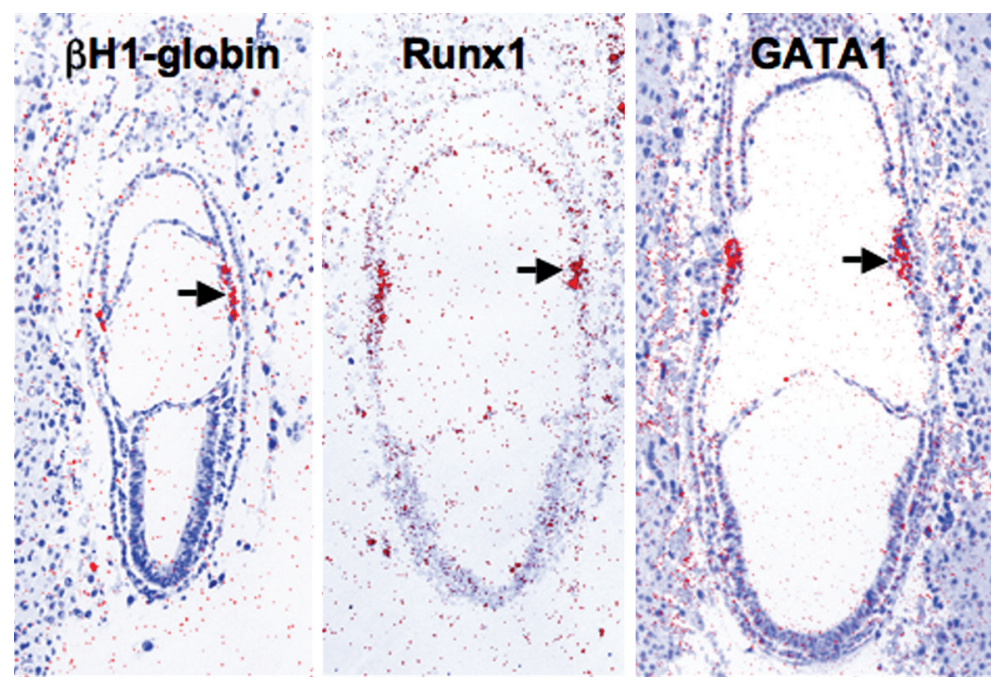

Fig. 4. Spatial expression patterns of $\beta H 1$-globin, Runx1 and GATA1 transcripts in neural plate stage (E7.5) mouse embryos. All three of these genes are expressed in emerging yolk sac blood islands (arrows).

cells (Wadman, 1997). Both Scl and Lmo2 are expressed throughout the extraembryonic mesoderm layer of the early yolk sac in mouse embryos and continue to be expressed in forming blood islands (Kallianpour, 1994; Silver, 1997). Targeted disruption of $\mathrm{Scl}$ and of Lmo2 in mice each leads to a complete block in the emergence of embryonic hematopoietic cells and to embryonic death in utero at E9.5-10.5 (Warren, 1994; Shivdasani, 1995; Robb, 1995). Consistent with these findings, Scl is required for hemangioblast cell transition to hemogenic endothelium (Lancrin, 2009). Interestingly, in vivomarking of scl-expressing cells labels primitive erythroid cells but fails to mark endothelial cells in the developing mouse embryo (Bockamp, 2009). The cis-regulatory domains responsible for Lmo2 expression in endothelial versus yolk sac blood cells have come under recent scrutiny (Landry, 2009). These studies, taken together, indicate that Scl and Lmo2 are central to the emergence of primitive hematopoiesis and highlight the ongoing difficulties in untangling the emergence of blood and endothelium in the mammalian embryo.

Several members of the Kruppel-like transcription factor family are known to activate erythroid-specific genes. The prototypical member, KLF1 (EKLF) was originally cloned from erythroid cells and is expressed not only in definitive but also in primitive erythroid precursors (Miller, 1993; Southwood, 1996). Targeted disruption of KLF1 in the mouse leads to severe abnormalities of definitive erythroid cells and in fetal death in utero at E15.5 (Perkins, 1995; Nuez, 1995). While it was initially thought that KLF1 primarily regulated the adult $\beta$-globin gene through interactions with its CACC motif, it is now recognized that KLF1 also regulates the expression of multiple erythroid-specific genes, including cytoskeletal proteins and alpha hemoglobin stabilizing protein (Hodge, 2006; Pilon, 2006). Consensus binding sites for KLF1 and GATA1 are found near the cis-regulatory regions of many erythroid-specific genes.

Three other KLF family members have been implicated in the regulation of globin genes in primitive erythroid cells. Studies of KLF2-null mouse embryos revealed significant decreases in $\beta \mathrm{H} 1$ and cy-globin transcripts in primitive erythroid cells (Basu, 2005).
Human $\varepsilon$-globin transgenes were also reduced in mice lacking KLF2, suggesting that this transcription factor may play a similar role in humans. KLF4 knockdown in zebrafish embryos leads to decreased embryonic globin gene expression (Gardiner, 2007). Consistent with this finding, KLF4 preferentially binds the CACC sites in the promoters of the embryonic compared to the adult $\beta$-globin genes. Finally, KLF6-null mouse embryos display severe anemia at E10.5 consistent with an important role in the regulation of yolk sac hematopoiesis (Matsumoto, 2006).

The transcription factor Runx1 has been associated with the emergence of intraembryonic hematopoietic stem cells, since targeted disruption of Runx1 leads to a lack of aortic clusters at E10.5 and fetal hemorrhage and death by E12.5 (Wang, 1996; North, 1998). However, Runx1 is expressed not only in intraembryonic clusters but also earlier in development within nascent yolk sac blood islands (Fig. 4; Lacaud, 2002) and in circulating primitive erythroid cells (North, 1999). Recent evidence indicates that targeted disruption of Runx 1 in mice leads to decreased expression of GATA1 and KLF1 transcription factors as well as to mild abnormalities in the morphology of primitive erythroid cells (Yokomizo, 2008). Runx1 expression in the yolk sac is directly regulated by SCL, providing evidence that complex transcriptional networks are central to the emergence and maturation of primitive erythroid cells (Landry, 2008).

Transcription factors function within the context of modified chromatin domains. Unlike definitive erythroid cells, the $\mathrm{\beta H} 1$ - and عy-globin genes in primary primitive erythroid cells of the mouse lie within a large hyperacetylated domain (Kingsley, 2006). The importance of chromatin remodeling in primitive erythroid cells has recently been established by studies of the chromatin remodeling enzyme brahma related gene 1 (BRG1) as well as p400/ mDomino. Targeted disruption of BRG1 in mouse embryonic blood and endothelium results in the failure of primitive erythroid cells to transcribe embryonic and adult $\beta$-globin genes as well as the $\zeta$-globin gene (Griffen, 2008). This leads to a severe thalassemic syndrome with apoptosis of primitive erythroid cells and death in utero at E10.5-E11. Similarly, disruption of the SWI2/ SNF2 family ATPase, p400/mDomino, which is a core subunit of a large chromatin-remodeling complex, displayed marked anemia and fetal death at E11.5 (Ueda, 2007).

\section{Summary}

As surmised by Maximov one hundred years ago (1909), primitive erythroid cells constitute a unique erythroid lineage distinct from later definitive erythroid cells. Primitive erythroblasts are the first blood cells to differentiate within the mammalian embryo and failure of this lineage to differentiate leads to early fetal demise. Features unique to primitive erythroid cells include their immense size and hemoglobin content, their expression of predominantly embryonic hemoglobins, and their differentiation within the vascular space. However, primitive erythroid cells share many similarities with their definitive counterparts, including a maturational process characterized by progressive hemoglobin accumulation, nuclear condensation, and ultimately enucleation. While it has long been thought that primitive erythroblasts share many similarities with the red cells of non-mammalian 
species which remain nucleated throughout their lifespan, it is now recognized that primitive erythropoiesis is in fact mammalian in character and serves as a useful model for the study of erythroid cell maturation.

\section{Acknowledgements}

We thank laboratory coworkers, colleagues and collaborators for valuable discussions and insights. We acknowledge the National Institutes of Health (USA) and the Strong Children's Research Center (University of Rochester) for funding support.

\section{References}

BASU P, MORRIS PE, HAAR JL, WANI MA, LINGREL JB, GAENSLER KM, LLOYD JA (2005). KLF2 is essential for primitive erythropoiesis and regulates the human and murine embryonic beta-like globin genes in vivo. Blood106: 25662571

BATEMAN AE, COLE RJ (1971). Stimulation of haem synthesis by erythropoietin in mouse yolk-sac-stage embryonic cells. J Emb Exp Morph 26: 475-480.

BARKER JE (1968). Development of the mouse hematopoietic system: I. Types of hemoglobin produced in embryonic yolk sac and liver. Dev Bio/18: 14-29.

BELAOUSOFF M, FARRINGTON SM, BARON MH (1999). Hematopoietic induction and respecification of A-P identity by visceral endoderm signaling in the mouse embryo. Development 125: 5009-5018.

BETHLENFALVAY NC, BLOCK M (1970). Fetal erythropoiesis. Maturation in megaloblastic (yolk sac) erythropoiesis in the C57BI/6J mouse. Acta Haematol 44: 240-245.

BIELINSKA M, NARITA N, HEIKINHEIMO M, PORTER SB, WILSON DB (1996). Erythropoiesis and vasculogenesis in embryoid bodies lacking visceral yolk sac endoderm. Blood 88: 3720-3730.

BOCKAMP E, ANTUNES C, LIEBNER S, SCHMITT S, CABEZAS-WALLSCHEID N, HECK R, OHNNGEMACH S, OESCH-BARTLOMOWICZ B, RICKERT C, SANCHEZ MJ, HENGSTLER J, KAINA B, WILSON A, TRUMPP A, ESHKIND $\mathrm{L}$ (2009). In vivofate mapping with SCL regulatory elements identifies progenitors for primitive and definitive hematopoiesis in mice. Mech Dev126: 863-872.

BOUSSIOS T, BERTLES JF, GOLDWASSER E (1988). Erythropoietin-receptor characteristics during the ontogeny of hamster yolk sac erythroid cells. $J$ Biol Chem 264: 16017-16021.

BROTHERTON TW, CHUI DHK, GAULDIE J, PATTERSON M (1979). Hemoglobin ontogeny during normal mouse fetal development. Proc Nat/Acad Sci USA76: 2853-2857.

CHENG X, HUBER TL, CHEN VC, GADUE P, KELLER GM (2008). Numb mediates the interaction between Wnt and Notch to modulate primitive erythropoietic specification from the hemangioblast. Development 135: 3447-3458.

CHENG Y, WU W, KUMAR SA, YU D, DENG W, TRIPIC T, KING DC, CHEN KB, ZHANG $Y$, DRAUTZ D, GIARDINE B, SCHUSTER SC, MILLER W, CHIAROMONTE F, ZHANG Y, BLOBEL GA, WEISS MJ, HARDISON RC (2009). Erythroid GATA1 function revealed by genome-wide analysis of transcription factor occupancy, histone modifications, and mRNA expression. Genome Res 19: 2172-2184.

COLE RJ, PAUL J (1966). The effects of erythropoietin on haem synthesis in mouse yolk sac and cultured foetal liver cells. J Emb Exp Morph 15: 245-260.

DE LA CHAPELLE A, FANTONI A, MARKS P (1969). Differentiation of mammalian somatic cells: DNA and hemoglobin synthesis in fetal mouse yolk sac erythroid cells. Proc Natl Acad Sci USA 63: 812-819.

DYER MA, FARRINGTON SM, MOHN D, MONDY JR, BARON MH (2001). Indian hedgehog activates hematopoiesis and vasculogenesis and can respecify neurectodermal cell fate in the mouse embryo. Development 128: 1717-1730.

EMA M, YOKOMIZO T, WAKAMATSU A, TERUNUMA T, YAMAMOTO M, TAKAHASHI S (2006). Primitive erythropoiesis from mesodermal precursors expressing VE-cadherin, PECAM-1, Tie2, endoglin, and CD34 in the mouse embryo. Blood 108: 4018-4024.

EILKEN HM, NISHIKAWA S, SCHROEDER T (2009). Continuous single-cell imaging of blood generation from haemogenic endothelium. Nature 12: 896900.
FANTONI A, DE LA CHAPELLE A, RIFKIND RA, MARKS PA (1968). Erythroid cell development in fetal mice: synthetic capacity for different proteins. JMo/Bio/33: 79-91.

FANTONI A, DE LA CHAPELLE A, MARKS PA (1969). Synthesis of embryonic hemoglobins during erythroid cell development in fetal mice. J Biol Chem244: 675-681.

FARACE MG, BROWNBA, RASCHELLA G, ALEXANDERJ, GAMBARI R, FANTONI A, HARDIES SC, HUTCHISON CA 3RD, EDGELL MH (1984). The mouse bht gene codes for the $z$ chain of embryonic hemoglobin. J Biol Chem 259: 71237128.

FERKOWICZ MJ, STARR M, XIE X, LI W, JOHNSON SA, SHELLEY WC, MORRISON PR, YODER MC (2003). CD41 expression defines the onset of primitive and definitive hematopoiesis in the murine embryo. Development130: 4393-4403.

FERKOWICZ MJ, YODER MC (2005). Blood island formation: longstanding observations and modern interpretations. Exp Hemato/33: 1041-1047.

FRASER ST, ISERN J, BARON MH (2007). Maturation and enucleation of primitive erythroblasts during mouse embryogenesis is accompanied by changes in cellsurface antigen expression. Blood 109: 343-352.

FUJIWARA Y, BROWNE CP, CUNNIFF K, GOFF SC, ORKIN SH (1996). Arrested development of embryonic red cell precursors in mouse embryos lacking transcription factor GATA-1. Proc Natl Acad Sci USA 93: 12355-12358.

FUJIWARA T, O'GEEN H, KELES S, BLAHNIK K, LINNEMANN AK, KANG YA, CHOI K, FARNHAM PJ, BRESNICK EH (2009) Discovering hematopoietic mechanisms through genome-wide analysis of GATA factor chromatin occupancy. Mol Cel/36: 667-681.

FURUTA C, EMA H, TAKAYANAGI S, OGAERI T, OKAMURA D, MATSUI Y, NAKAUCHI H (2006). Discordant developmental waves of angioblasts and hemangioblasts in the early gastrulating mouse embryo. Development 133 : 2771-2779.

GARDINER MR, GONGORA MM, GRIMMOND SM, PERKINS AC (2007). A global role for zebrafish klf4 in embryonic erythropoiesis. Mech Dev 124: 762-774.

GRASS JA, BOYER ME, PAL S, WU J, WEISS MJ, BRESNICK EH (2003). GATA1-dependent transcriptional repression of GATA-2 via disruption of positive autoregulation and domain-wide chromatin remodeling. Proc Natl Acad Sci USA 100: 8811-8816.

GRASS JA, JING H, KIM SI, MARTOWICZ ML, PAL S, BLOBEL GA, BRESNICK EH (2006). Distinct functions of dispersed GATA factor complexes at an endogenous gene locus. Mol Cel/ Bio/26: 7056-7067.

GRIFFIN CT, BRENNAN J, MAGNUSON T (2008). The chromatin-remodeling enzyme BRG1 plays an essential role in primitive erythropoiesis and vascular development. Development 135: 493-500.

HAAR JL, ACKERMAN GA (1971). A phase and electron microscopic study of vasculogenesis and erythropoiesis in the yolk sac of the mouse. Anat Rec 170 199-224.

HADLAND BK, HUPPERT SS, KANUNGO J, XUE Y, JIANG R, GRIDLEY T, CONLON RA, CHENG AM, KOPAN R, LONGMORE GD (2004). A requirement for Notch1 distinguishes 2 phases of definitive hematopoiesis during development. Blood 104: 3097-3105.

HODGE D, COGHILL E, KEYS J, MAGUIRE T, HARTMANN B, MCDOWALL A, WEISS M, GRIMMOND S, PERKINS A (2006). A global role for EKLF in definitive and primitive erythropoiesis. Blood 107: 3359-3370.

HUBER K, KOUSKOFF V, FEHLING HJ, PALIS J, KELLER G (2004). Haemangioblast commitment is initiated in the primitive streak of the mouse embryo. Nature 432: 625-630.

ISERN J, FRASER ST, HE Z, BARON MH (2008). The fetal liver is a niche for maturation of primitive erythroid cells. Proc Nat/Acad Sci USA 105: 6662-6667.

JI RP, PHOON CK, ARISTIZABAL O, MCGRATH KE, PALIS J, TURNBULL DH (2003). Onset of cardiac function during early mouse embryogenesis coincides with entry of primitive erythroblasts into the embryo proper. Circ Res 92: 133135.

JOHANSSON BM, WILES MV (1995). Evidence for involvement of activin A and bone morphogenetic protein 4 in mammalian mesoderm and hematopoietic development. Mol Cell Biol15: 141-151.

JOLLIE WP (1990). Development, morphology, and function of the yolk-sac placenta of laboratory rodents. Teratology $41: 361-381$. 
KALLIANPUR AR, JORDAN JE, BRANDT SJ (1994). The SCL/TAL-1 gene is expressed in progenitors of both the hematopoietic and vascular systems during embryogenesis. Blood 83: 1200-1208.

KENNEDY M, D'SOUZA SL, LYNCH-KATTMAN M, SCHWANTZ S, KELLER G (2007). Development of the hemangioblast defines the onset of hematopoiesis in human ES cell differentiation cultures. Blood109: 2679-2687.

KIERAN MW, PERKINS AC, ORKIN SH, ZON LZ (1996). Thrombopoietin rescues in vitro erythroid colony formation from mouse embryos lacking the erythropoietin receptor. Proc Nat/ Acad Sci USA 93: 9126-9131.

KIMURA T, SONODA Y, IWAI N, SATOH M, YAMAGUCHI-TSUKIO M, IZUI T, SUDA M, SASAKI K, NAKANO T (2000). Proliferation and cell death of embryonic primitive erythrocytes. Exp Hemato/28: 635-641.

KINGSLEY PD, MALIK J, FANTAUZZO KA, PALIS J (2004). Yolk sac-derived primitive erythroblasts enucleate during mammalian embryogenesis. Blood 104: 19-25.

KINGSLEY, PD, MALIK, J, EMERSON, RL, BUSHNELL, TP, MCGRATH, KE, BLOEDORN, LA, BULGER, M, PALIS, J (2006). "Maturational" globin switching in primary primitive erythroid cells. Blood 104: 1667-1672.

LACAUD G, GORE L, KENNEDY M, KOUSKOFF V, KINGSLEY P, HOGAN C, CARLSSON L, SPECK N, PALIS J, KELLER G (2002). Runx 1 is essential for hematopoietic commitment at the hemangioblast stage of development in vitro. Blood 100: 548-466.

LANCRIN C, SROCZYNSKA P, STEPHENSON C, ALLEN T, KOUSKOFF V, LACAUD G (2009). The haemangioblast generates haematopoietic cells through a haemogenic endothelium stage. Nature 12: 892-895

LANDRY JR, BONADIES N, KINSTON S, KNEZEVIC K, WILSON NK, ORAM SH, JANES M, PILTZ S, HAMMETT M, CARTER J, HAMILTON T, DONALDSON IJ, LACAUD G, FRAMPTON J, FOLLOWS G, KOUSKOFF V, GÖTTGENS B (2009). Expression of the leukemia oncogene Lmo2 is controlled by an array of tissue-specific elements dispersed over $100 \mathrm{~kb}$ and bound by Tal1/Lmo2, Ets, and Gata factors. Blood113: 5783-5792.

LANDRY JR, KINSTON S, KNEZEVIC K, DE BRUIJN MF, WILSON N, NOTTINGHAM WT, PEITZ M, EDENHOFER F, PIMANDA JE, OTTERSBACH K, GÖTTGENS B (2008). Runx genes are direct targets of Scl/Tal1 in the yolk sac and fetal liver. Blood111: 3005-3014.

LEE R, KERTESZ N, JOSEPH SB, JEGALIAN A, WU H (2001). Erythropoietin (Epo) and EpoR expression and 2 waves of erythropoiesis. Blood 98: 14081415.

LIN C-S, LIM S-K, D'AGATI V, CONSTANTINI F (1996). Differential effects of an erythropoietin receptor gene disruption on primitive and definitive erythropoiesis. Genes Dev 10: 154-164

LUGUS JJ, PARK C, MA YD, CHOI K (2009). Both primitive and definitive blood cells are derived from Flk-1+ mesoderm. Blood113: 563-566.

MAKITA T, HERNANDEZ-HOYOS G, CHEN TH, WU $\mathrm{H}$, ROTHENBERG EV, SUCOV HM (2001). A developmental transition in definitive erythropoiesis: erythropoietin expression is sequentially regulated by retinoic acid receptors and HNF4. Genes Dev 15: 889-901.

MATSUMOTO N, KUBO A, LIU H, AKITA K, LAUB F, RAMIREZ F, KELLER G, FRIEDMAN SL (2006). Developmental regulation of yolk sac hematopoiesis by Kruppel-like factor 6. Blood 107: 1357-1365.

MAXIMOW AA (1909). Untersuchungen uber blut und bindegewebe 1. Die fruhesten entwicklungsstadien der blut- und binde- gewebszellan bein saugetierembryo, bis zum anfang der blutbilding unden leber. Arch Mikroskop Anat 73: 444-561.

MCGANN JK, SILVER L, LIESVELD J, PALIS J (1997). Erythropoietin-receptor expression and function during the initiation of murine yolk sac erythropoiesis. Exp Hemato/25: 1149-1157

MCGRATH KE, KONISKI AD, MALIK J, PALIS J (2003). Circulation is established in a stepwise pattern in the mammalian embryo. Blood 101: 1669-1676.

MCGRATH KE, KINGSLEY PD, KONISKI AD, PORTER RL, BUSHNELL TP, PALIS J (2008). Enucleation of primitive erythroid cells generates a transient population of "pyrenocytes" in the mammalian fetus. Blood 111: 2409-2417.

MILLER IJ, BIEKER JJ (1993). A novel, erythroid cell-specific murine transcription factor that binds to the CACCC element and is related to the Krüppel family of nuclear proteins. Mo/ Cell BiO/13: 2776-2786.

MORIOKA K, TONÉ S, MUKAIDA M, TAKANO-OHMURO H (1998). The apoptotic and nonapoptotic nature of the terminal differentiation of erythroid cells. Exp
Cell Res 240: 206-217.

MOTOYAMA N, KIMURA T, TAKAHASHI T, WATANABE T, NAKANO T (1999). $b c /-x$ prevents apoptotic cell death of both primitive and definitive erythrocytes at the end of maturation. $J$ Exp Med 11: 1691-1698.

NEUBAUER H, CUMANO A, MÜLLER M, WU H, HUFFSTADT U, PFEFFER K (1998). Jak2 deficiency defines an essential developmental checkpoint in definitive hematopoiesis. Cel/93: 397-409.

NORTH T, GU T-L, STACEY T, WANG Q, HOWARD L, BINDER M, MARÍNPADILLA M, SPECKNA (1999). Cbfais required for the formation of intra-aortic hematopoietic clusters. Development 126: 2563-2575.

NUEZ B, MICHALOVICH D, BYGRAVE A, PLOEMACHER R, GROSVELD F (1995). Defective haematopoiesis in fetal liver resulting from inactivation of the EKLF gene. Nature 375: 316-318.

PALIS J, KENNEDY M, ROBERTSON S, WALL C, KELLER G (1999): Development of erythroid and myeloid progenitors in the yolk sac and embryo proper of the mouse embryo. Development 126: 5073-5084.

PALIS J, KINGSLEY PD, MCGRATH KE (1995): Initiation of hematopoiesis and vasculogenesis in murine yolk sac explants. Blood86: 156-163.

PARK C, MA YD, CHOIK (2005). Evidence for the hemangioblast. Exp Hemato/33: 965-970

PEARSON S, SROCZYNSKA P, LACAUD G, KOUSKOFF V (2008). The stepwise specification of embryonic stem cells to hematopoietic fate is driven by sequential exposure to Bmp4, activin A, bFGF and VEGF. Development 135: 15251535.

PERKINS AC, SHARPE AH, ORKIN SH (1995). Lethal beta-thalassaemia in mice lacking the erythroid CACCC-transcription factor EKLF. Nature 375: 318-322.

PESCHLE C, MAVILIO F, CARÈ A, MIGLIACCIO G, MIGLIACCIO AR, SALVO G SAMOGGIA P, PETTI S, GUERRIERO R, MARINUCCI M, LAZZARO D, RUSSO G, MASTROBERARDINO G (1985). Haemoglobin switching in human embryos: asynchrony of zetał alpha and epsilon‡ gamma-globin switches in primitive and definite erythropoietic lineage. Nature 313: 235-238.

PILON AM, NILSON DG, ZHOU D, SANGERMAN J, TOWNES TM, BODINE DM GALLAGHER PG (2006). Alterations in expression and chromatin configuration of the alpha hemoglobin-stabilizing protein gene in erythroid Kruppel-like factordeficient mice. Mol Cel/ Bio/26: 4368-4377.

QIU C, OLIVIER EN, VELHO M, BOUHASSIRA EE (2008). Globin switches in yolksac-like primitive and fetal-like definitive red blood cells produced from human embryonic stem cells. Blood111: 2400-2408.

RICHMOND TD, CHOHAN M, BARBER DL (2005). Turning cells red: signal transduction mediated by erythropoietin. Trends Cel/ Bio/15: 146-155.

ROBB L, LYONS I, LI R, HARTLEY L, KÖNTGEN F, HARVEY RP, METCALF D, BEGLEY CG (1995). Absence of yolk sac hematopoiesis from mice with a targeted disruption of the sc/gene. Proc Nat/ Acad Sci USA 92: 7075-7079.

ROBERT-MORENO A, ESPINOSA L, SANCHEZ MJ, DE LA POMPA JL, BIGAS A (2007). The notch pathway positively regulates programmed cell death during erythroid differentiation. Leukemia 21: 1496-1503.

SABIN FR (1920). Studies on the origin of blood vessels and red blood corpuscles as seen in the living blastoderm of chicks during the second day of incubation. Contrib Embryo/9: 213-262.

SANGIORGIF, WOODS CM, LAZARIDESE (1990). Vimentin downregulation is an inherent feature of murine erythropoiesis and occurs independently of lineage. Development 110: 85-96.

SASAKI K, KENDALL MD (1985). The morphology of the haematopoietic cells of the yolk sac in mice with particular reference to nucleolar changes. J Anat 140 279-295

SHIVDASANI RA, MAYER EL, ORKIN SH (1995). Absence of blood formation in mice lacking T-cell leukemia oncoprotein tal-1/SCL. Nature 373: 432-434

SILVER L, PALIS J (1997). Initiation of murine embryonic erythropoiesis: a spatial analysis. Blood 89: 1154-1164.

SILVA M, BENITO A, SANZ C, PROSPER F, EKHTERAE D, NUÑEZ G FERNANDEZ-LUNA JL (1999). Erythropoietin can induce the expression of bcl$\mathrm{x}(\mathrm{L})$ through Stat5 in erythropoietin-dependent progenitor cell lines. JBio/Chem 274: $22165-22169$.

SMITH RA, GLOMSKI CA (1977). Embryonic and fetal hemopoiesis in the Mongolian gerbil (Meriones unguiculatus). Anat Rec 189: 499-517. 
SORENSON GD (1961). An electron microscopic study of hematopoiesis in the yolk sac. Lab Invest 10: 178-193.

SOUTHWOOD CM, DOWNS KM, BIEKER JJ (1996). Erythroid Krüppel-like factor exhibits an early and sequentially localized pattern of expression during mammalian erythroid ontogeny. Dev Dyn 206: 248-259.

STEINER R, VOGEL H (1973). On the kinetics of erythroid cell differentiation in fetal mice: I. Microspectrophotometric determination of the hemoglobin content in erythroid cells during gestation. J Cell Physio/81: 323-338.

TAKASHINA T (1987). Haemopoiesis in the human yolk sac. J Anat 151: 125-135.

TEWARIR, GILLEMANS N, WIJGERDE M, NUEZB, VON LINDERN M, GROSVELD F, PHILIPSEN S (1998). Erythroid Krüppel-like factor (EKLF) is active in primitive and definitive erythroid cells and is required for the function of 5'HS3 of the beta-globin locus control region. EMBO J17: 2334-2341.

TIEDEMANN K (1977). On the yolk sac of the cat. Cell Tiss Res 183: 171-189.

TOBER J, KONISKI A, MCGRATH KE, VEMISHETTI R, EMERSON R, DE MESYBENTLEY KKL, WAUGH R, PALIS J (2007). The megakaryocyte lineage originates from hemangioblast precursors and is an integral component both of primitive and definitive hematopoiesis. Blood 109: 1433-1441.

TSANG AP, VISVADER JE, TURNER CA, FUJIWARA Y, YU C, WEISS MJ, CROSSLEY M, ORKIN SH (1997). FOG, a multitype zinc finger protein, acts as a cofactor for transcription factor GATA-1 in erythroid and megakaryocytic differentiation. Cel/90: 109-119.

TSANG AP, FUJIWARA Y, HOM DB, ORKINSH (1998). Failure of megakaryopoiesis and arrested erythropoiesis in mice lacking the GATA-1 transcriptional cofactor FOG. Genes Dev 15: 1176-1188.

TSUJI-TAKAYAMA K, OTANI T, INOUE T, NAKAMURA S, MOTODA R, KIBATA $M$, ORITA K (2006). Erythropoietin induces sustained phosphorylation of STAT5 in primitive but not definitive erythrocytes generated from mouse embryonic stem cells. Exp Hemato/34: 1323-1332.

UEDA T, WATANABE-FUKUNAGA R, OGAWA H, FUKUYAMA H, HIGASHI Y, NAGATA S, FUKUNAGA R (2007). Critical role of the p400/mDomino chromatin-remodeling ATPase in embryonic hematopoiesis. Genes Cel/s 12: 581-592.

UENO H, WEISSMAN IL (2006). Clonal analysis of mouse development reveals a polyclonal origin of yolk sac blood islands. Dev Ce//11: 519-533.

WADMAN IA, OSADA H, GRÜTZ GG, AGULNICK AD, WESTPHAL H, FORSTER A, RABBITTS TH (1997). The LIM-only protein Lmo2 is a bridging molecule assembling an erythroid, DNA-binding complex which includes the TAL1, E47, GATA-1 and Ldb1/NLI proteins. EMBO J16: 3145-3157.

WANG Q, STACY T, BINDER M, MARIN-PADILLA M, SHARPE AH, SPECK NA (1996). Disruption of the Cbfa2 gene causes necrosis and hemorrhaging in the central nervous system and blocks definitive hematopoiesis. ProcNat/Acad Sci USA 93: 3444-3449.

WARREN AJ, COLLEDGE WH, CARLTON MB, EVANS MJ, SMITH AJ, RABBITTS TH (1994). The oncogenic cysteine-rich LIM domain protein is essential for erythroid development. Cel/78: 45-57.

WELLS RMG (1979). Hemoglobin-oxygen affinity in developing embryonic erythroid cells of the mouse. J Comp Physio/129: 333-338.

WHITELAW E, TSAI SF, HOGBEN P, ORKIN SH (1990). Regulated expression of globin chains and the erythroid transcription factor GATA-1 during erythropoiesis in the developing mouse. Mol Cel/ Biol10: 6596-6606,.

WINNIER G, BLESSING M, LABOSKY PA, HOGAN BL (1995). Bone morphogenetic protein-4 is required for mesoderm formation and patterning in the mouse. Genes Dev 9: 2105-2116.

WONG PMC, CHUNG SW, CHUI DHK, EAVES CJ (1986). Properties of the earliest clonogenic hematopoietic precursors to appear in the developing murine yolk sac. Proc Natl Acad Sci USA 83: 3851-3854.

WU H, LIU X, JAENISCH R, LODISH HF (1995). Generation of committed erythroid BFU-E and CFU-E progenitors does not require erythropoietin or the erythropoietin receptor. Cel/83: 59-67.

YAMADA Y, WARREN AJ, DOBSON C, FORSTER A, PANNELL R, RABBITTS TH (2000). The oncogenic LIM-only transcription factor Lmo2 regulates angiogenesis but not vasculogenesis in mice. Proc Natl Acad Sci USA 97: 320-324.

YOKOMIZO T, HASEGAWA K, ISHITOBIH, OSATO M, EMA M, ITOY, YAMAMOTO $\mathrm{M}$, TAKAHASHI S (2008). Runx1 is involved in primitive erythropoiesis in the mouse. Blood 111: 4075-4080.

YOSHIDA H, KAWANE K, KOIKE M, MORI Y, UCHIYAMA Y, NAGATA S (2005). Phosphatidylserine-dependent engulfment by macrophages of nuclei from erythroid precursor cells. Nature 437: 754-758.

YU M, RIVA L, XIE H, SCHINDLER Y, MORAN TB, CHENG Y, YU D, HARDISON R, WEISS MJ, ORKIN SH, BERNSTEIN BE, FRAENKEL E, CANTOR AB (2009). Insights into GATA-1-mediated gene activation versus repression via genome-wide chromatin occupancy analysis. Mol Ce//36: 682-695.

ZAMBIDIS ET, PEAULT B, PARK TS, BUNZ F, CIVIN CI (2005). Hematopoietic differentiation of human embryonic stem cells progresses through sequential hematoendothelial, primitive, and definitive stages resembling human yolk sac development. Blood 106: 860-870.

ZIMMERMANN F, RICH IN (1997). Mammalian homeobox B6 expression can be correlated with erythropoietin production sites and erythropoiesis during development, but not with hematopoietic or nonhematopoietic stem cell populations. Blood 89: 2723-2739. 


\section{Further Related Reading, published previously in the Int. J. Dev. Biol.}

See our recent Special Issue Placenta edited by Joan S. Hunt and Kent L. Thornburg at: http://www.ijdb.ehu.es/web/contents.php?vol=54\&issue=2-3

Tracing the hemangioblast during embryogenesis: developmental relationships between endothelial and hematopoietic cells

Thierry Jaffredo, Karine Bollerot, Daisuke Sugiyama, Rodolphe Gautier and Cécile Drevon Int. J. Dev. Biol. (2005) 49: 269-277

Of birds and mice: hematopoietic stem cell development

Isabelle Godin and Ana Cumano

Int. J. Dev. Biol. (2005) 49: 251-257

Embryonic development of the human hematopoietic system

Manuela Tavian and Bruno Péault

Int. J. Dev. Biol. (2005) 49: 243-250

Multilineage hematopoietic progenitor activity generated autonomously in the mouse yolk sac: analysis using angiogenesis-defective embryos

Christine Rampon and Philippe Huber

Int. J. Dev. Biol. (2003) 47: 273-280

Embryonic stem cells and transgenic mice in the study of hematopoiesis S H Orkin

Int. J. Dev. Biol. (1998) 42: 927-934

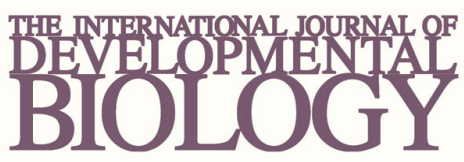

Volume 54 Nos. 6/7

Special Issue
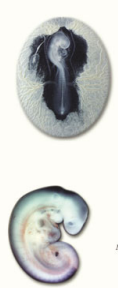

(2) $(6)$
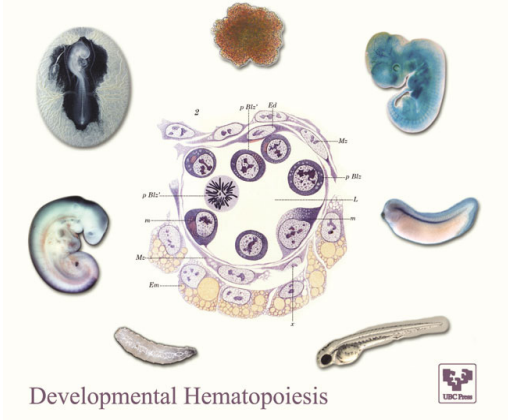

Developmental Hematopoiesis

5 yr ISI Impact Factor $(2009)=3.253$

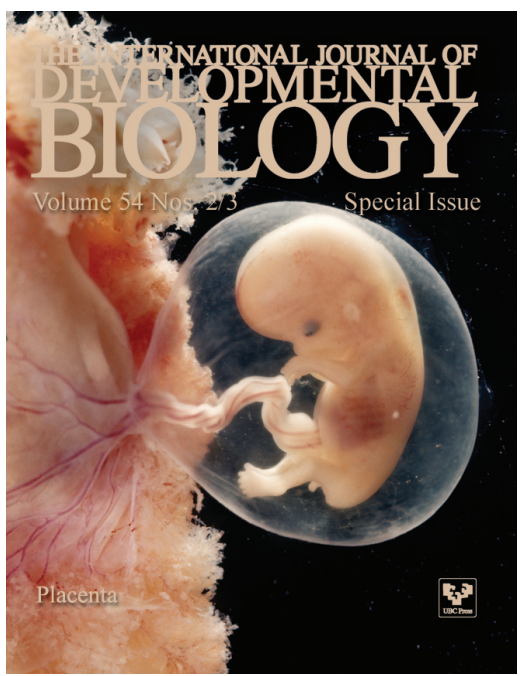

